\title{
Framing Ethnic Tolerance, Political Tolerance and Voting Behaviour
}

\section{Mohd Azmir Mohd Nizah}

Post-Graduate Student, Government and Civilization Studies Department, Faculty of Human Ecology, Universiti Putra Malaysia

Email: azmirnizah@usim.edu.my

Jayum A. Jawan

Professor, Government and Civilization Studies Department, Faculty of Human Ecology, Universiti Putra Malaysia

Sarjit Singh A/L Darshan Singh

Associate Professor, Social and Development Sciences Department, Faculty of Human Ecology, Universiti Putra Malaysia

Ku Hasnita Ku Samsu

Senior Lecturer, Government and Civilization Studies Department, Faculty of Human Ecology, Universiti Putra Malaysia

\section{Doi:10.5901/mjss.2015.v6n4s1p365}

\begin{abstract}
This article is an attempt to bridge both the concept of ethnic and political tolerance into one account. It also is an attempt to make a connection between both ethnic and political tolerance with the studies of voting behaviour. Using qualitative methodology with content analysis approach and reviewing past literature, this article proposed a development of democraticrational learning framework, a hybrid perspective from democratic learning and rational choice theories. As to date, the nonexistence of any single model that explains both areas may pave to a new avenue in understand tolerance ethnically and politically and its importance in the study of voting behaviour. The proposed framework is perhaps contributed to the current body of knowledge of both theories. It is significance where ethnic and politics perceived as most important matter, and tolerance become increasingly worldwide agenda in managing multi-diversity society. Evidences are discussed further.
\end{abstract}

Keywords: national unity; nations building; election studies; rational choice; democratization

\section{Introduction}

The fifth challenge of the Malaysia National Vision Policy has clearly mention on its aim to establish a matured, liberal and tolerant society in which Malaysians of all colors and creeds are free to practice and profess their customs, cultures and religious belief and yet feeling that they are belong to one nation, (Mahathir Mohamad, 1991). This aim is based on the fact that, Malaysia is ethnically, culturally and religiously diverse society, where historically its record for some conflicts, evidently in 1969, 1998, and 2001(Fazilah, 2008; Hari \& Singh, 2010; Mohd Azmir \& Paimah, 2012) and several "red-dot" occasions occur in its multi-ethnic relations. Except for the 13 May tragedy, ethnically heterogeneous Malaysia had a remarkable and enviable record of political stability and general social peace, but there is tendency for every political issue to be transformed into communal one. (Crouch, 1996; Zakaria, 1989). As Malaysia has been consider a successful nation and a model for developing countries (Lijphart, 1977; Shamsul, 2005), it is then a huge challenge to maintain its racial harmony and tolerance (Cheah, 2004). While Malaysia political climate is ever negotiated through ethnic line (Jayum A. Jawan \& King, 2004; Jayum A. Jawan \& Mohammad Agus, 2008), it indicates that ethnic political tolerant is material and imperative factor for Malaysia's political stability and continuity.

However, voting behaviour becomes more complex in Malaysia, when ethnicity and urban and rural factors is increasingly becoming an important predictor. This concern is specific with electoral implications of tolerance behaviour. Therefore, an empirical, well-specified, and scholarly analysis of such situations should be treating as urgency. Thus, this analysis is an attempt to provide a better and clearer framework for the study of ethnic and political tolerance under one account. Then, article analysis aimed at making connection of the ethnic political tolerance with voting behaviour study. This study, then proposed a framework for future study of ethnic political tolerance and voting behaviour with limitation of 
democratic learning and rational choice theory. Ethnic political tolerance is a significant and dynamic segment to discuss. A rationale analysis on ethnic political tolerance behaviour may provide a better understanding on tolerance literature and its effects toward voting behaviour in Malaysia may be a significant variables, and worth to be research. Future study may also benefitted from the propose framework in understanding tolerances and charting new election strategy.

\section{Literature Review}

This section looks at the various definitions of tolerance, a framework for categorizing the ethnic and political tolerance, as well as voting behaviour studies.

\subsection{Tolerance}

Tolerance in Latin means, "to bear, withstand and endure". It is crucial to study tolerance, as people are diverse in nature, and equally important to understand that only tolerance ensure the survival of human kind. Tolerance exists in the space between difference and similarities. The study of tolerance began empirically in 1950's with major concern of civil rights movements in United States of America, the influx of immigrations in European, and establishment of newly independent countries with pluralistic in nature. According to APA Dictionary of Psychology, tolerance is refers to acceptance of others whose actions, beliefs, physical capabilities, religion, customs, ethnicity, nationality, and so on is differ from one's own. It also define as a fair and objective attitude toward points of view different from one's own (American Psychological Association, 2007, p. 944). In the works of various scholars, tolerance is typically defined as the willingness to extend basic procedural rights and respect for the civil liberties to groups one strongly dislikes or ideas that one opposes (Sullivan, Piereson, \& Marcus, 1982), and universal civic duty, particularly free speech rights, of unpopular groups, because of its bourgeois transformations. Gibson (2007) defines tolerance as a willingness to put up with disagreeable ideas and groups. Tolerance is understood as a minimal concept that involves non-interference with practices or forms of life of others, including granting equal legal and political rights even if one disapproves of them. (Persell, Green, \& Gurevich, 2001; Triandafyllidou \& The Accept Pluralism Project, 2013).

Hazama (2010) define tolerance as an attitude toward objectionable groups, or out-groups. Meanwhile, recent scholar define tolerance from sociological as respect for diversity, openness, inclusiveness, and diversity to all ethnicities, races, and walks of life and a matter of educating ourselves to respect others (Corneo \& Jeanne, 2009; Florida, 2003; Ramadan, 2010). On the practical and behaviour point of view, Jayum A. Jawan \& Mohammad Agus (2008) define tolerance as manifestation of give and take attitude, which is must for greater political, economic, and social goods.

Tolerance also does not about equality, fairness or neutrality only, but rather a matter of balance, that requires consensual action of both sides to ensure the desired results by assent rather than force (Ahmad Tarmizi, Sarjit Singh Gill, Razaleigh, \& Puvaneswaran Kunasekaran, 2013). Tolerance often has been regard as one of the core elements of democracy and indicator of social cohesion (Lee, 2013). Therefore, tolerance can be consider as dynamic attribute or behaviour that is embed within democratic values, and serve in specific social goals. Walzer (1997) suggest that tolerance need encompasses range of attitude, that need to be learn, which fostered by knowledge, openness, communication, and freedom of thought, conscience, and belief (UNESCO, 1985).

Based on various literature above, there is no doubt that, tolerance is one of the most fundamental personality traits in contemporary world, where integration, migration, globalization, and cross cultural processes took place, which matters due to its connectivity to a set of beliefs on legitimacy and appropriateness of self-expression (Gibson, 1992). Summarized from Abbarno (2013), tolerance is not about extending expressive rights to different group only, but also exercising their own rights to political expression and participation. Thus, it is clearly, scholar has defines tolerance from various aspect, but all agree that tolerance is a value (abstract), attitude and behaviour. Therefore, due consideration to all definition given, tolerance in this specific article is defined as learned value, positive openness attitude toward others that translate into active behaviour for greater political aims including exercising votes in election. It must be noted that, this definition and conceptualization of tolerance are bound with the concerned of the extension of one's political rights.

Tolerance has become an increasingly vibrant matter in modern multi diversity society culturally, ethnically, religiously and politically. Tolerance has been regard as indispensable key for plural societies and democratic competition. Various researcher and scholars has emphasized on the importance of tolerance in their respective society. (Aaron J Abbarno, 2011; Ahmad Tarmizi et al., 2013; Clark, 2008; Furedi, 2012; Gibson \& Gouws, 2001; Inglehart, 1997; Jackman, 1977; Peffley, Knigge, \& Hurwitz, 2001; Walzer, 1997). Empirical evidence suggests tolerance can contribute to social stability and harmony. (Almond \& Verba, 1989; Cheah, 2004). Yet, it is an ideal that has been long time regard as an act of cowardice, and had not been a virtue at all. (Hazard, 1953). However, as emphasized by Wan Mohd Nor (2014), 
from Islamic philosophy point of view, it is an act of cowardice not because of coward, but because powerless, in a state of humility as human being that subject to Allah's power.

The word tolerance is often revealed in various literatures either on the field of religious, medical, anthropological and psychological.(Shyryn, Assem, \& Zhanat, 2013). However, often, misconception of tolerance has been acknowledge as either "far leftist", "far rightist", "centre-left" or natulist from its virtue, which became the central of debate among religious and political individual, as Kymlicka (2012) summarized as misleading model of multiculturalism, rhetorical approach and shifted to a discourse that emphasizes on "civic integration," "social cohesion," "common values," and "shared citizenship" rather than assimilates. Tolerance also does not about equality, fairness or neutrality per say, but rather a matter of balance, that requires consensual action of both sides to ensure the desired results by assent rather than force.(Ahmad Tarmizi et al., 2013). Tolerance- therefore, is a respect for diversity that promotes peaceful coexistence. Tolerance is not a moral imperative only, but it is an important part of a system's behaviour. It is exhibited when the system is healthy, and when it is within a larger environment which contributes to its well-being. (Orban, 2008).

Various conflict, wars, or issues are basically due to the absence of tolerance attitude, for example, the conflict between white and non-white, majority-minority conflict in most part of the world, or war that occurred between nations, or religious differentiation. As Furedi (2012) noted, because the world has change, so do tolerance, but it is not for a better. This is merely due to misleading model of tolerance in the western world as acknowledge by Kymlicka (2012). As quoted on American philosopher, Michael Walzer (1997) "toleration makes difference possible; difference makes toleration necessary".

\subsubsection{Ethnic Tolerance}

The term ethnic originated from Latin word- ethnicus that bring to meaning of nation. Historically, it also refers to people or to "races". Therefore, ethnic means a group of people that correlated with genetics, cultural, historical, and status likeliness. Ethnic tolerance can be define as a positive act of individual or group citizens to put up their differences with respect to the cultural and tradition practices, history and values, and physic-biological aspects for a greater political aims. However, often research are pertains to immigrants than native ethnic groups (Cote \& Erickson, 2009; Crepaz \& Damron, 2008; Weldon, 2006) or religious differentiation. (Ahmad Tarmizi et al., 2013; Eisenstein, 2006; Jha, 2012). Wilson (1998) did criticize the deficiency of related literature on this specific inter-ethnic tolerance topic. The work of Mansor (1999) in Petaling Jaya, Selangor, and Penang also suggest that ethnic tolerance shows some positive social consequences on ethnic relations, in fact, ethnicity became secondary after societal goals. It can be conclude that the ethnic tolerance level in urban setting is higher than in rural setting. Thus, clearly, ethnic factor is an obvious importance variable in understanding politics in the Malaysian plural society (Ratnam, 1967), even ethnic consciousness in Malaysia will decline further. (Mansor, 1999). However, recent cases prove that ethnic salient is still major factor in Malaysian ethnic relations despite major studies that focus on national unity undertook. Tolerant behaviour, politically and ethnically are equally vital in order to guarantee Malaysia's economically, politically, and socially stable. (Banton, 1985; Jayum A. Jawan, 1996; Sanusi, 1989). Therefore, in order to achieve that specific aim, a broad public support for basic democratic values is necessary. As Gibson, Duch, \& Tedin, (1992) characterize a liberal democratic citizen is one who is believes in individual liberty and who is politically tolerant, and one who supports basic democratic institutions and processes, clearly set a standard measurement of tolerant individual. Base on principle that attitudes do affect behaviour it lead to an assumption that citizens, who embrace these norms in principle attitudinally, may apply them behaviorally.

\subsubsection{Political Tolerance}

Political tolerance is not itself an attitude, but instead is a hypothetical construct that characterizes the priorities assigned in the instance of value conflict. (Gibson \& Bingham, 1982). It manifests the complexity of ideas that deep-rooted in human history which difficult to comprehend. (Sniderman, 1975). Despite the complexity of political tolerance, yet it gains an exceptional scholarly attention ever since. Political tolerance can be understand as "a willingness to permit the expression of ideas or interests one opposes" (Sullivan et al., 1982) that lays for an expressive society. While, Avery (1988) defines political tolerance as the degree of extended socio-political ideas, beliefs, or interest tolerated or opposed. Political tolerance usually refers as to allow political freedoms to those who are politically different. Specifically, political tolerance is to allow an opposition attitude or character to state actions that limit opportunities for citizens, individually or in groups, to compete for political power. (Dahl, 1970). Therefore, within the traditional definitions of political tolerant, this study will offer definition of political tolerance as an extended act by individual or a group of citizens to support or to oppose in political activities (in this study to their voting behaviors') that may differ from one owns for a greater political 
aims.

Researches on political tolerance also found out that the high level of political tolerance contribute to sustain democratic value and reducing ethnic conflict. (Arwine \& Mayer, 2012; Seligson \& Caspi, 1983). Widmalm \& Oskarsson (2013) in their recent analysis of Madhya Pradesh state, India found interesting evidence on political tolerance. They argue, urban settlers are found to be more tolerant than rural citizen, which is in line with previous literature. However, surprisingly, the level of political tolerance between Congress (I) Parties's (deemed to be secular) and Bharatiya Janata Party (BJP) (perceived as Hindu nationalist) of urban and rural citizens does not follow the pattern predicted by the literature. All literature carries the same coins that determinants of political tolerant are not distinguish significantly from determinant of ethnic tolerance. Gender, marital status, religiosity, workplace, education, urbaneness, social network, and political party and preferences considered as established determinant of ethnic political tolerance. However, the question remains as how can democracy prosper when citizen undermine the necessity of ethnic political tolerance?

The model of democratic learning, suggest that political tolerant are increasing over time in more stable democracies, and in countries that uses federal systems, which subsequently ends the theory of democratic elitism. The model also suggests that democratic activism, enhanced political tolerance. (Pateman, 2003; Peffley \& Rohrschneider, 2003). The model shared the same spirit of Aristotelian of active citizens and John Stuart Mill's 1861 on Democratic Participation and Political Education. The model outlined that active, engage, and participation is a cause rather than a consequence of political tolerance. The consequences of political tolerance have been highlight, whereas significant numbers of literature investigated on the determinants, nature, and level of tolerance attitudes. Without political tolerance, the ethnically pluralistic society may lack of necessary lubricant that would facilitate working of democratic institutions. (Gouws, 1996; World Public Opinion.Org, 2009). However, whether in what ways, and how ethnic political tolerance and voting behaviour are linked, and thus effected, remains an open question in the literature.

\subsection{Voting Behaviour}

Voting is an essential form of political participation. It is one of the essences of democratic values. Voting is the key mechanism of consensus in democratic society. (Lipset, 1960). Understanding national voting behaviour and various factors that influences on voter have been tremendously analyse in terms of fair election system, voter influences, voter's ethnic politics, voting simulation models and voting pattern and trends. (Fernando, 2013; Kottonau \& Pahl-Wostl:, 2004; Maznah Mohamad, 2008; Mohammad Redzuan \& Amer Saifude, 2013; Rowden, Lloyd, \& Gilbert, 2014; Thomas, 2008). In order to explore these various influences, several distinguish model has been proposed, including sociological, psychosocial, behavioural and rational choice model. (Ajzen, 1985, 1991; Antunes, 2010; Ghazali Mayudin, 2006; Kottonau \& Pahl-Wostl:, 2004; Rowden et al., 2014).

This article is focused on rational choice model as centre of discourse for some reasons. Rational choice theory first explains from the economic point of view, where consumers rationally decided for their own interest. Rational choice presupposes there is comparing behaviour of voters, political parties, and government with goals of maximising utility and consistency based on rationality. For the most part, proponents of rational choice theory explain that voter is a strategic actor that strategically and tactically behaves on casting their vote (Cox, 1997). Rational choice not only able to explain the possibility of making predictions on voter behaviour, but also made possible to compare between individuals, political parties and government behaviour as well. The model operates based on three fundamental premises.

Firstly, the model assume that all decision made by voters is rational, that is guided by self- interest based on the principle of maximization of action utility. Secondly, it is possible to make prediction about the consequences of decision made by voters, which result from different choices, which based on the consistency of democratic political system. Thirdly, despite consistency factor, there are however, some level of uncertainty that sufficiently important to allow different options that contributes to democratic system to bloom. In short, rational choice theory is based on rationality, consistency and uncertainty to explain voter, political parties and government behaviour in election that account to concrete action apart from ideology. There are two main perspectives on parsimonious approach of rational choice model that is Evaluative; which is based on voters' judgement of the parties or representatives performance on policies and public interests, and Non-Evaluative perspectives; that drive on personal affective ties of patronage, family, clan, and ethnic considerations (Lindberg \& Morrison, 2008).

However, some studies suggest that Rational choice theory has a very low explanatory power of voting behaviour, (Antunes, 2010) though through tactical voting measures it more thoroughly. (Fisher, 2004). On the other hand, rational choice theories (rational behaviour or rational decision making) can account for social stability and for social change, that can readily analyze both social conflict and social cooperation. (Harsanyi, 1969). Epistemologically, it's individualist versus collectivist character between rational choice and ethnic. (Malešević, 2002) Nevertheless, when it comes to the 
voting behaviour, voters do rationally cast their vote individually but the result is in collective nature.

The Malaysia 2008 general election produces the completely different story but strategic voting or tactical voting becomes increasing important. Rational choice model able to clarify the reasons why some voters do vote differently in consecutive elections for a reason, rational choice model breeds tactical voting due to cost-effective principle in nature.

\section{Research Methodology}

In doing so, this study employed qualitative design with content analysis. Past literature is reviewed, synced common factor for ethnic and political tolerance values, and then framed in bound with the voting behaviour studies. Past literature of tolerance often segmentized ethnic tolerance and political tolerance into different account as suggested by Weldon (2006). However, due to the absence of ethnic migration factor in Malaysia, and politics are always translated into a communality (Jayum A. Jawan \& King, 2004), it is therefore, ethnic and political tolerance are better explained synonymously, at least in Malaysias' local situation. Thus, with limitation of democratic learning theory, this study will analyse the attitude and perception factor of ethnic tolerance, while the democratic values and civic and political participation tenets is to explain political tolerance. As for the voting behaviour, the evaluative and the non-evaluative factor will be analysed through. Due to insufficient literature that explain both ethnic political tolerance and voting behaviour in one synonymous account, therefore content analysis may work best with current data.

\section{Discussion}

There is no doubt, that ethnic political tolerance certainly requires sacrifice that is necessary for the sake of survival of the nation. When ethnic political tolerance does matter, so do elections, and when elections matter, and thus so do electoral behaviour. Nevertheless, more complicated, political behaviour (in this article, voting) are highly dependent on the electoral logic of three dominant ethnic, namely, the Malays, the Chinese and the Indians. Since recent $12^{\text {th }}$ and $13^{\text {th }}$ General Election result had shown a distinctive pattern of voting behaviour among Malaysian, including urban-rural relationship and perceptions, an act of protest voting, ethnic political tolerance and strategic voting become more salient feature.(Brown, 2005; Fernando, 2013; Guan, 2013; Maznah Mohamad, 2008; Vejai Balasubramaniam, 2006). Although, to some account, this may indicate the other way, as recent researcher found that U.S. 2008 election is consider as "most-racial" despite Obama historically decorates as first Non-White U.S. President. It is acknowledged that urban areas reflecting the nation identity, where it is a primary economic, political activity, and social rewards are put into play.(Omer, Romann, \& Goldblatt, 2013; Shamsul \& Fauzi, 2007), but recent voting trends has made it more distinguish as compare to previous. Recent studies on heterogeneous society found that tolerance is increase due to exposure on diverse political opinions, but it decreases political participation. (Mutz, 2005).

Using democratic learning model, it is clear that both segment of ethnic and political tolerance are effecting vice versa. The model combines both democratization and study of tolerance into one framework by synthesized macro and micro level traits independently and jointly affects political tolerance. (Peffley \& Rohrschneider, 2003). The theory explicitly regards the importance of tolerance to a liberal democracy system. The model suggests that citizens become more tolerant when they are exposed to the democratic politics, with (1) political tolerance should be greater in more stable democracies over period of time; that assumption is based on the longer democratic values in a nation, the more opportunity to apply democratic norms, that contribute to increase citizens' appreciation of tolerance. (2) Federal systems hypothetically provide citizens with multiple points of access and encourage political compromise that should increase the levels of tolerance. As suggested by Lijphart (1999), federal system is 'gentle' institutions that provide multiple access points, which are contrast with unitary system that result the creation of federalism-unitary political tolerance divide. (3) While at micro level, democratic activism (civil liberties) enhances political tolerance. Participation in civic associations that promote liberal attitudes and attract open-minded people as member's breed tolerance attitudes, whereas associations that promotes dogmatism could breed intolerance. (Cote \& Erickson, 2009). Democracy works best when individual or citizen actively engage, which often perceived to be more tolerance and vice-versa. When citizens apply their democratic values into behaviour, they contribute to public policy process, and broaden the political expression opportunities. (Gibson, 1992). On the other hand, it is worthwhile to investigate tolerance as driver for political participation that due to omitted variables bias. (Sullivan et al., 1982). Some scholar also regards that give-and-take behaviour is a consequence from learning process that generates tolerance. (Pateman, 2003; Peffley \& Rohrschneider, 2003). In short, the model stresses on the citizens democratic engagement as well as government policy towards unpopular groups. The central argument of democratic learning theory proponent is tolerant will grow over time via participation in civic liberties, which resulted the end of democratic elitism theory and the beginning of democratic learning 
theory; and participation as a cause, rather than a consequence. (Aaron Joseph Abbarno, 2013; Pateman, 2003).

However, there are some empirical evidences that conclude otherwise. Firstly, political tolerance and voting behaviour not related directly at all. A citizen, who are possess high education, and live in urban area are categorically more tolerant, and therefore more participator. That is not the case, because this assumption is deriving from primordial "democratic personality". (Sniderman, 1975). Secondly, tolerance may fit best in less participatory democracy in plural societies; in other words, political tolerance is conflicting with voting behaviour rather than complementary in nature. (Aaron Joseph Abbarno, 2013). Although ethnic political tolerance and voting behaviour do not quite satisfy that the more tolerant citizens, the more participatory they will be hypothesis. Nevertheless, there is positive relationship between ethnic political tolerances and voting behaviour that gives little attention to the possibility of tolerance that shapes voting behaviour rather than reverse. However, none the above variables supports the elitist theory of democracy, which left the democratic learning theory to explain the relationship between tolerance and voting behaviour convincingly.

But the question of ethnic political tolerance effect on voting behaviour remains opaque. It is particularly difficult because ethnic political tolerance determinants that shape toleration also tend to influence voting behaviour. The challenge lies on how to connect ethnic political tolerance to voting behaviour in order to conceptualize tolerance as a contributor to political participation. (as in this study, voting behaviour).

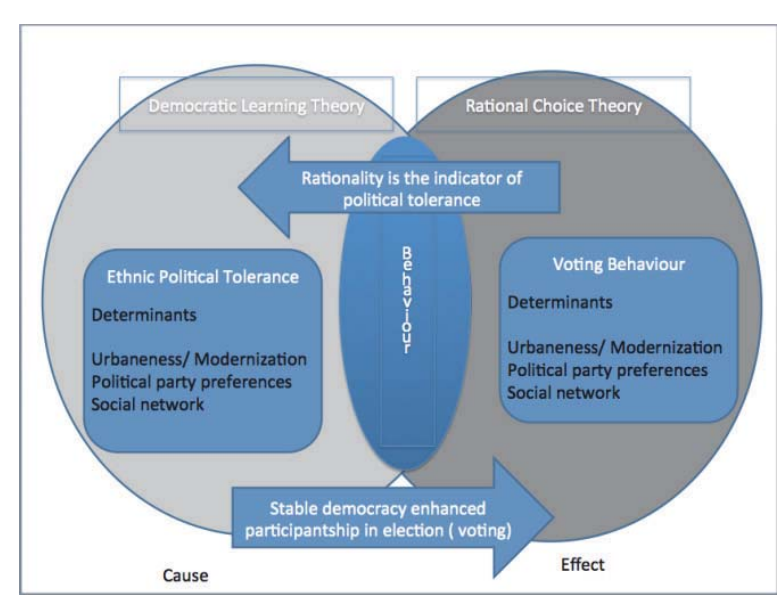

Figure 1. Conceptual Framework

Thus, this article propose a conceptual framework ( Figure 1) for further investigation, framing, and making empirical argument in understanding the association, connection and consequence of ethnic political tolerance on voting behaviour.

\section{Conclusion}

The obtainability of democratic learning theory explain both ethnic and political tolerance with political participation (voting exercise) has become the major factor to further investigate the consequence of ethnic and political tolerance on voting behaviour. At least three conclusion statements can be made. First, the study of tolerance, socially and politically has become the most expanding fields of study due to modernization, migration, and globalization that made worlds more pluralistic and beyond nation-state definition. Therefore, tolerance has become the key value in managing such changes. Because tolerance, socially and politically can be taught and learned, only democratic learning theory capable to offer better explanation and promoting tolerance. Therefore, this study is best suit with the framework of democratic learning theory. Secondly, the study of voting behaviour is getting more attention from political scientist due to its dynamism and more complex as individualistic nature are more salient rather than group action. This has leaded this field of study to data-rich of research. The wave of democratization in Eastern Europe, Asia and Arabs present opportunity for democracy to bloom, and it offer rationality in political participant. Therefore, examining voting behaviour from rational choice theory view will offer more insight in understanding the dynamism of voting behaviour. Thirdly, it seemingly that voting behaviour is disseminating with tolerance. Therefore, explaining voting behaviour from rational choice perspective may intensify to the study of tolerance from democratic learning theory. Most importantly, the lack of study of both tolerance and voting behaviour simultaneously may pave to a new avenue and add to the body of knowledge of both topics. 


\section{References}

Abbarno, A. J. (2011). Tolerance Matters: A Cognitive Dissonance Model of the Effects of Protecting Rights and Restricting Liberties on Political Attitudes and Behavior. Washington.

Abbarno, A. J. (2013). The Behavioral Consequence of Political Tolerance. University of Pittsburgh.

Ahmad Tarmizi, . Talib, Sarjit Singh Gill, ., Razaleigh, . Muhamat Kawangit, \& Puvaneswaran Kunasekaran, .. (2013). Religious Tolerance: The Key between One ASEAN One Community. Life Science Journal, 10(4), 1382-1385.

Ajzen, I. (1985). From Intentions to Actions: A Theory of Planned Behavior. In J. Kuhl \& J. Beckmann (Eds.), Action Control:From Cognition to Behavior (pp. 11-39). Heidelberg, Germany: Springer.

Ajzen, I. (1991). The Theory of Planned Behavior. Organizational Behavior and Human Decision Processes, 50, 179-211.

Almond, G. A., \& Verba, S. (1989). The Civic Culture. California: SAGE Publications Inc.

American Psychological Association. (2007). APA Dictionary of Psychology. California: American Psychological Association.

Antunes, R. (2010). Theoretical Models of Voting Behaviour. Exedra, 4, 145-170.

Arwine, A., \& Mayer, L. (2012). The Impact of Tolerance on Political Behavior (pp. 1-20). Portland, Oregon.

Avery, P. G. (1988). Political Tolerance Among Adolescents. Theory and Research in Social Education, 16(3), 183-201.

Banton, M. (1985). Promoting Racial Harmony (1st ed.). Cambridge, United Kingdom: Cambridge University Press.

Brown, G. (2005). Playing the (non)ethnic card: The electoral system and ethnic voting patterns in Malaysia. Ethnopolitics, 4(4), 429445. doi:10.1080/17449050500348675

Cheah, B. K. (2004). The Challenge of Ethnicity; Building a Nation in Malaysia. (B. K. Cheah, Ed.) (1st ed., p. 170). Singapore: Marshall Cavendish International.

Clark, J. N. (2008). Tolerance As a Way of Life. Texas Tech University.

Corneo, G., \& Jeanne, O. (2009). A Theory of Tolerance. Journal of Public Economics, 93(5), 691-702.

Cote, R. R., \& Erickson, B. H. (2009). Untangling the Roots of Tolerance: How Forms of Social Capital Shape Attitudes Toward Ethnic Minorities and Immigrants. American Behavioral Scientist, 52(12), 1664-1689. doi:10.1177/0002764209331532

Cox, G. W. (1997). Making Votes Counts. Cambridge: Cambridge University Press.

Crepaz, M. M. L., \& Damron, R. (2008). Constructing Tolerance: How the Welfare State Shapes Attitudes About Immigrants. Comparative Political Studies, 42(3), 437-463. doi:10.1177/0010414008325576

Crouch, H. A. (1996). Government and Society in Malaysia. New York: Cornell University Press.

Eisenstein, M. A. (2006). Rethinking the Relationship between Religion and Political Tolerance in the US. Political Behavior, 28(4), 327348. doi:10.1007/s11109-006-9014-5

Fazilah, I. (2008). The Influence of Individual Attributes On Inter-Ethnic Tolerance among Early Youth in Selangor. Universiti Putra Malaysia.

Fernando, J. M. (2013). The urban drift in Kuala Lumpur in the 2008 General Election : a return to the old ways ? Malaysian Journal of Democracy and Election Studies, 1(1), 24-41.

Fisher, S. D. (2004). Definition and Measurement of Tactical Voting: The Role of Rational Choice. British Journal of Political Science, 34(01), 152. doi:10.1017/S0007123403220391

Florida, R. (2003). Cities and the Creative Class. City \& Community, 2(March), 3-19.

Furedi, F. (2012). "On Tolerance." Policy: A Journal of Public Policy and Ideas, 28(2), 30-37.

Ghazali Mayudin, . (2006). Demokrasi dan Pilihan Raya dalam Malaysia. In . Ghazali Mayudin, . Jamaie Hamil, . Sity Daud, \& . Zaini Othman (Eds.), Demokrasi Kepimpinan dan Keselamatan dalam Politik Malaysia. Bangi, Selangor: Penerbit Universiti Kebangsaan Malaysia.

Gibson, J. L. (1992). The political consequences of intolerance - cultural conformity and political freedom. American Political Science Review, 86, 338-356. doi:10.2307/1964224

Gibson, J. L., \& Bingham, R. D. (1982). On the Conceptualization and Measurement of Political Tolerance. The American Political Science Review, 76(3), 603-620. doi:10.2307/1963734

Gibson, J. L., Duch, R. M., \& Tedin, K. L. (1992). Democratic Values and the Transformation of the Soviet Union. The Journal of Politics, 54(02), 329-371. doi:10.2307/2132030

Gibson, J. L., \& Gouws, A. (2001). Making Tolerance Judgments : The Effects of Context , Local and National. The Journal of Politics, 63(4), 1067-1090.

Gouws, A. (1996). Intolerance in Kwazulu-Natal: Illustrating the Complexity of Tolerance Attitudes. Politikon: South African Journal of PoliticalStudies, 23(2), 22-35. doi:10.1080/02589349608705034

Guan, L. H. (2013). Steadily Amplified Rural Votes Decide Malaysian Elections. Singapore.

Hari, S., \& Singh, H. (2010). Ethnic Conflict in Malaysia Revisited. Commonwealth \& Comparative Politics, 39(1), 42-65. doi:10.1080/713999532

Harsanyi, J. C. (1969). Rational Choice Models of Political Behavior vs. Functionalist and Conformist Theories. World Politics, 21(4), 513-538.

Hazard, P. (1953). The European Mind: The Critical Years (1680-1715). (trnsl. JL May, Ed.). New Haven: Yale University Press.

Inglehart, R. (1997). Modernization and Postmodernization: Cultural, Economic, and Political Change in 43 Societies. New Jersey: Princeton University Press.

Jackman, M. R. (1977). Prejudice, Tolerance, and Attitudes toward Ethnic Groups. Social Science Research, 6(2), 145-169. 
doi:10.1016/0049-089x(77)90005-9

Jayum A. Jawan. (1996). Conflict Resolution Through Consensus Building : Experiences from the Dayak Than Community of Sarawak, East Malaysia. Pertanika Journal of Social Sciences \& Humanities, 4(2), 121-127.

Jayum A. Jawan, \& King, V. T. (2004). Ethnicity \& Electoral Politics in Sarawak (p. 60). Bangi, Selangor: Penerbit Universiti Kebangsaan Malaysia.

Jayum A. Jawan, \& Mohammad Agus, Y. (2008). The 2008 General Elections: Implications for Ethnic Relations in Malaysia. In Globalising Religions and Cultures in the Asia Pacific (pp. 3-40). Adelaide: The University of Adelaide.

Jha, S. (2012). Trade , Institutions and Ethnic Tolerance : Evidence from South Asia. American Political Science Review (Vol. 107, pp. 806-832). California. doi:10.1017/S0003055413000464

Kottonau, J., \& Pahl-Wostl:, C. (2004). Simulating political attitudes and voting behavior. Journal of Artificial Societies and Social Simulation, 7(4).

Kymlicka, B. W. (2012). Multiculturalism : Success, Failure, and the Future. Washington DC.

Lee, F. L. F. (2013). "Tolerated One Way but Not the Other": Levels and Determinants of Social and Political Tolerance in Hong Kong. Social Indicators Research, (September 2013). doi:10.1007/s11205-013-0433-5

Lijphart, A. (1977). Democracy in plural societies: a comparative exploration. Yale: Yale University Press.

Lindberg, S. I., \& Morrison, M. K. C. (2008). Are African Voters Really Ethnic or Clientelistic ? Survey Evidence from Ghana. Political Science Quarterly, 123(1), 95-122.

Lipset, S. M. (1960). Political Man. London: Heinemann Educational Books Ltd.

Malešević, S. (2002). Rational choice theory and the sociology of ethnic relations: a critique. Ethnic and Racial Studies, 25(2), 193-212. doi:10.1080/01419870120109458

Mansor, M. N. (1999). Crossing Ethnic Borders in Malaysia Measuring the Fluidity of Ethnic Identity and Group Formation. Akademika, 55(Julai), 61-82.

Mohamad, M. (1991). The Way Forward-Vision 2020. www.wawasan2020.com. Retrieved from http://www.wawasan2020.com/vision/p2. $\mathrm{html}$

Mohamad, M. (2008). Malaysia - democracy and the end of ethnic politics? Australian Journal of International Affairs, 62(4), 441-459. doi:10.1080/10357710802480691

Mohammad Redzuan, O., \& Amer Saifude, G. (2013). The Voting Trend of the Parliamentary By-Elections After the Malaysian 12th General Election. Malaysian Journal of Democracy and Election Studies, 1(1), 96-115.

Mohd Azmir, M. N., \& Paimah, A. (2012). The Relationship of Urbanization on Perception of Ethnic Relations. Advances in Natural and Applied Sciences, 6(7), 1143-1149.

Mutz, D. C. (2005). Hearing the Other Side: Deliberative versus Participatory Democracy. Cambridge: Cambridge University Press.

Omer, I., Romann, M., \& Goldblatt, R. (2013). Geographical Scale Of Tolerance In The Urban Area. Journal of Urban Studies, 00(0), 118. doi:10.1111/juaf.12047

Orban, D. (2008). Tolerance as a Guiding Principle. Ibn Khaldun Lecture Series (pp. 1-4). Granada. Retrieved from http://www.davidorban.com/2008/04/holding-the-inaugural-ibn-khaldun-lecture-on-al-andalus/

Pateman, C. (2003). Participation and Democratic Theory. The Democracy Sourcebook, 40-48. doi:10.2307/2613634

Peffley, M., Knigge, P., \& Hurwitz, J. (2001). A Multiple Values Model of Political Tolerance. Political Research Quarterly, 54(2), 379406.

Peffley, M., \& Rohrschneider, R. (2003). Democratization and Political Tolerance in Seventeen Countries: A Multilevel Model of Democratic Learning. Political Research Quarterly, 56(3), 243-257. doi:10.1177/106591290305600301

Persell, C. H., Green, A., \& Gurevich, L. (2001). Civil Society, Economic Distress, and Social Tolerance. Sociological Forum, 16(2), 2-3.

Ramadan, T. (2010). The Quest For Meaning: Developing a Philosophy of Pluralism. London: Penguin Group.

Ratnam, K. J. (1967). Communalism and the Political Process in Malaya. Kuala Lumpur: University of Malaya Press.

Robert A Dahl. (1970). Polyarchy: Participation and opposition. Democratization (Vol. 54, p. 257). New Haven: Yale University Press. doi:polyarchy

Rowden, J., Lloyd, D. J. B., \& Gilbert, N. (2014). A Model of Political Voting Behaviours across Different Countries, 1-22. Retrieved from http://personal.maths.surrey.ac.uk/st/D.J.Lloyd/voter_paper.pdf

Sanusi, O. (1989). Ikatan Etnik dan Kelas Di Malaysia (1st ed., p. 84). Bangi, Selangor: Universiti Kebangsaan Malaysia.

Seligson, M. A., \& Caspi, D. (1983). Arabs in Israel: Political Tolerance and Ethnic Conflict. The Journal of Applied Behavioral Science, 19(1), 55-66.

Shamsul, A. B. (2005). The Construction And Management Of Pluralism : Sharing The Malaysian Experience. ICIP Journal, 2(1), 1-14.

Shamsul, A. B., \& Fauzi, M. S. (2007). City as a Reflection of National Identities : Early Comparison between Jakarta and Kuala Lumpur. Akademika, 70(Januari), 3-19.

Shyryn, U., Assem, B., \& Zhanat, B. (2013). Tolerance Features in the Structure of Worldview Culture (Based on the Current State Analysis of the Issue). Procedia - Social and Behavioral Sciences, 82, 921-932. doi:10.1016/i.sbspro.2013.06.373

Sniderman, P. M. (1975). Personality and Democratic Politics. Berkeley, CA: University of California Press.

Sullivan, J. L., Piereson, James, \& Marcus, George E. (1982). Political Tolerance \& American Democracy (Paperback.). Chicago: The University of Chicago Press.

Thomas, B. T. (2008, April). Election 2008 : Crossing the rubicon. ALIRAN, (April), 1-12.

Triandafyllidou, A., \& The Accept Pluralism Project. (2013). Pluralism and Social Cohesion: The Accept Pluralism Tolerance Indicators. 
Tolerance, Pluralism and Social Cohesion: Responding to the Challenges of the 21st Century in Europe. San Domenico di Fiesole, Italy.

UNESCO. (1985). Declaration Of Principles On Tolerance. UNESCO General Conference. Retrieved from http://www.unesco.org/web world/peace_library/UNESCO/HRIGHTS/124-129.HTM

Vejai Balasubramaniam, . (2006). Strengthening ethnic identity consciousness and the role of tactical voting in multi-racial Malaysia. Asian Ethnicity, 7(1), 75-88. doi:10.1080/14631360500498536

Walzer, M. (1997). On Toleration. New Haven: Yale University Press.

Wan Mohd Nor, W. D. (2014). The Meaning and Limit of Tolerance. Putrajaya.

Weldon, S. A. (2006). The Institutional Context of Tolerance for Ethnic Minorities: A Comparative, Multilevel Analysis of Western Europe. American Journal of Political Science, 50(2), 331-349. doi:DOI 10.1111/j.1540-5907.2006.00187.x

Widmalm, S., \& Oskarsson, S. (2013). Political Tolerance in India Descriptions and Explanations from the Heartland. Asian Survey, 53(3), 533-558.

World Public Opinion.Org. (2009). World Public Opinion on Political Tolerance A Study of 24 Nations (p. 26). Washington DC.

Zakaria, .Hj Ahmad. (1989). Malaysia: Quasi Democracy in a Divided Society. In L. Diamond, J. J. Linz, \& S. M. Lipset (Eds.), Democracy in Developing Countries (3rd ed., pp. 347-382). Colorado: Lynne Rienner Publishers. 